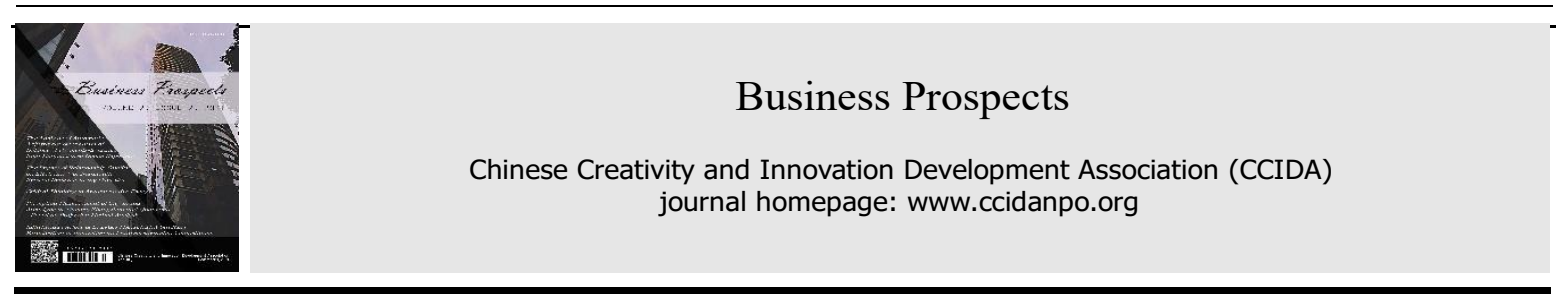

https://doi.org/10.52288/bp.27089851.2012.12.12

\title{
Perception Measurement of City Brand Archetype in Xiamen, Zhangzhou, and Quanzhou-Based on Projection Method Analysis
}

\author{
Yi-Han Yang ${ }^{1}$, Ying Wang ${ }^{1}$, Jing-Yi Zhu ${ }^{1}$ and Jing Wang ${ }^{2, *}$ \\ ${ }^{1}$ School of International Business, Xiamen University Tan Kah Kee College \\ ${ }^{2}$ Associate Professor of School of International Business, Xiamen University Tan Kah Kee College \\ * Correspondence: wangjing@xujc.com
}

Received: 2021.09.12; Accepted: 2021.10.10; Published: 2021.12.01

\begin{abstract}
City branding is the most concentrated embodiment of city image and the most valuable intangible asset of a city. City branding can attract investors, talents, tourists, and the public's attention to the city, as well as enhance the competitiveness of the city and bring greater economic benefits and growth potential to the city. Past studies in the context of city branding systematically focus on the development, shaping and communication. Little is known on the combination of city branding and brand archetypes. The projection technique is applied for this research. The objective of this research is to explore the archetypes of city brand based on the Twelve Chinese Cultural Archetypes theory, and takes Xiamen, Zhangzhou, and Quanzhou as the examples. The research reveals that Xiamen belongs to the archetype of "Beauty", Zhangzhou is close to the archetype of "Neighborhood", and Quanzhou belongs to the archetype of "Benevolent".
\end{abstract}

Keywords: City Branding; City Image; City Competitiveness; Projection Technique

\section{Introduction}

The development of Chinese cities has stepped into the era of branding, and city branding has been regarded as the high point of city competitiveness. In today's rapidly growing urbanization, cities are exploring the development of city brand in order to gain greater economic benefits and growth potential. By building up a good city brand image and spreading it, cities can attract investors, talents, tourists, and the public's attention. City branding is the most concentrated embodiment of city image and the most valuable intangible asset of a city. It is very important to promote the value-added of a city by shaping and spreading a city brand image. Xiamen, Zhangzhou, Quanzhou are key part of the area of the " 21 st Century Maritime Silk Road" in Fujian Province, and is also a window for the world to see China. The city branding of these three cities is important for spreading the image of Chinese cities, promoting the national cultural soft power, and establishing distinctive city brands in cities along "One Belt and One Road".

\section{Review of the Literature}

\subsection{City Brand Theories}

City branding is the use of marketing strategies to give a city a unique identity in the minds of citizens, visitors, and investors. As an extension of the essence of commercial branding, city brand represents the image, visibility, and reputation of a city, and is a comprehensive objective reflection of economic, environmental, and social changes inside and outside the city. City branding is an indispensable step for cities to improve their competitiveness (Shao et al., 2021). Li and Zhang (2021) believe that city brand is based on the city's historical heritage, geographic environment, industrial advantages, etc., to refine and integrate the distinctive city DNA, and is the core advantageous value delivered to the public in the process of promoting the city's image. Building city brand has become an important strategic initiative for many cities to promote development. Bao and Miao 
(2021) pointed out that in the process of drawing the city brand image concept, the relevant personnel should be based on our traditional historical and cultural system. And applying traditional visual symbols to show the concept of Chinese cities seeking common ground while preserving differences in the international arena, as well as the unique aesthetic values and deep historical heritage of the Chinese nation. A positive, positive city brand image can have greater attractiveness and competitive advantage, which is conducive to regional investment attraction, tourism development, talent introduction and citizen services. Urban brand development has gradually become an important force to boost the high-quality development of cities (Liu and Wang, 2021).

\subsection{Analysis of Theories Related to Brand Prototypes}

American scholars Margaret Mark and Carol S. Pearson first introduced the concept of archetypes to the field of branding, arguing that mythical archetypes can be used to create deeply rooted brands. In China, Liu et al. (2018) constructed a framework of cultural archetypes for Chinese brands and divided them into 12 specific archetypes. This research focuses on the projective measurement of Xiamen, Zhangzhou, and Quanzhou using this Chinese cultural archetype framework.

Table 1. Prototype Value Symbols.

\begin{tabular}{|c|c|}
\hline Archetypes & Value Symbols \\
\hline The Hero & $\begin{array}{l}\text { Everyone has the potential to be a hero. Heroes all over the world have one thing in } \\
\text { common, bravery and perseverance. }\end{array}$ \\
\hline The Jester & $\begin{array}{l}\text { A comedian who loves jokes and tells people that life is to be treated in a way that } \\
\text { amuses and entertains }\end{array}$ \\
\hline The Wise Man & Harmony, experience, wisdom, spiritual belonging, spiritual unity \\
\hline $\begin{array}{c}\text { The Kindly } \\
\text { Mother }\end{array}$ & $\begin{array}{l}\text { The image of a mother is great and hardworking. She is kind, loving and selfless, and } \\
\text { her attachment to her children often keeps her waiting for a lifetime }\end{array}$ \\
\hline The Filial & Filial piety, hoping for good luck and long life for parents \\
\hline The Confidant & Friends who know, appreciate, trust and care for you often guide your life \\
\hline $\begin{array}{l}\text { The } \\
\text { Neighborhood }\end{array}$ & Harmony, cordiality, and mutual help \\
\hline The Lover & Love, romance, love is the only \\
\hline The Benevolent & $\begin{array}{l}\text { Responsibility, duty, mission, care for the disadvantaged, minors, left-behind children. } \\
\text { Care for the well-being of the collective }\end{array}$ \\
\hline The Gentleman & Ambitious in career; calm a d relaxed in life; friendly in interpersonal relationship \\
\hline The Beauty & Beautiful, healthy, happy, free, energetic, and sensible modern women \\
\hline The Child & Childlike innocence, purity, truthfulness, being loved, often to be cared for \\
\hline
\end{tabular}

Source: Liu et al. (2018).

\section{Research Method}

The projection technique is a basic method of qualitative research techniques. Projection is also the psychological tendency of individuals to unconsciously reflect their attitudes, emotions, personality, and other psychological characteristics on externally relevant things. Through projection, the research detects the perception of different city brands in the minds of the public. This research uses psychological projection method to explore respondents' first perception of city brand image through interviews. The interviews were then categorized and key factors extracted, and summarized in conjunction with the Chinese brand culture archetypes constructed by Liu et al. (2018). Finally, the brand culture archetype image is paired. This paper measures the brand image of three cities, Xiamen, Zhangzhou, and Quanzhou, mainly in four dimensions: economic environment, human history, anthropomorphic characteristics, and city brand story.

The research used an in-depth interview method to talk to the respondents in a one-on-one manner. To explore the interviewees' emotions, opinions, and attitudes through continuous follow-up questions. 
Table 2. Interview Questions.

\begin{tabular}{|c|c|}
\hline Dimensionality & Problem Description \\
\hline \multirow{2}{*}{$\begin{array}{c}\text { Economic } \\
\text { Environment }\end{array}$} & $\begin{array}{l}\text { What do you know about Xiamen/Zhangzhou/Quanzhou? (From the economic } \\
\text { environment, development status) }\end{array}$ \\
\hline & $\begin{array}{l}\text { What are the similarities and differences between Xiamen/Zhangzhou/Quanzhou? (From } \\
\text { the economic environment, development status) }\end{array}$ \\
\hline \multirow{3}{*}{ Human History } & $\begin{array}{l}\text { Have you ever been to Xiamen/Zhangzhou/Quanzhou? What is your first impression of } \\
\text { these three cities? }\end{array}$ \\
\hline & $\begin{array}{l}\text { What are the city characteristics of Xiamen/Zhangzhou/Quanzhou? (From a humanistic } \\
\text { point of view) }\end{array}$ \\
\hline & What city history comes to mind when you think of Xiamen/Zhangzhou/Quanzhou? \\
\hline \multirow{2}{*}{$\begin{array}{l}\text { Anthropomorphic } \\
\text { features }\end{array}$} & $\begin{array}{l}\text { If you take Xiamen/Zhangzhou/Quanzhou as a person, what would you think of him? } \\
\text { (You can start from age, character, appearance, temperament, mental state, etc.) }\end{array}$ \\
\hline & $\begin{array}{l}\text { Why do you think Xiamen/Zhangzhou/Quanzhou are such people? What aspects of the city } \\
\text { make you feel this way? }\end{array}$ \\
\hline \multirow{2}{*}{ City Story } & $\begin{array}{l}\text { Are there any city stories from Xiamen/Zhangzhou/Quanzhou that stand out to you? } \\
\text { Do you like Xiamen/Zhangzhou/Quanzhou? Why do you like/dislike it? }\end{array}$ \\
\hline & $\begin{array}{l}\text { If you are allowed to live in Xiamen/Zhangzhou/Quanzhou for a period, how will you live } \\
\text { your life? }\end{array}$ \\
\hline
\end{tabular}

Source: Author's own compilation

4. Research process

4.1. Object Selection

Table 3. Interviewee information.

\begin{tabular}{ccccc}
\hline Number & Gender & Age & Profession & Live \\
\hline P1 & Male & 18 & Students & Zhangzhou \\
P2 & Male & 20 & Students & Quanzhou \\
P3 & Female & 30 & Teachers & Zhangzhou \\
P4 & Female & 19 & Students & Fuzhou \\
P5 & Male & 20 & Students & Xiamen \\
P6 & Female & 20 & Students & Xiamen \\
P7 & Male & 18 & Students & Sanming \\
P8 & Male & 26 & Freelance & Xiamen \\
P9 & Female & 19 & Students & Zhangzhou \\
P10 & Female & 22 & Freelance & Quanzhou \\
P11 & Male & 25 & Staff & Zhangzhou \\
P12 & Female & 19 & Students & Zhangzhou \\
P13 & Male & 25 & Staff & Xiamen \\
P14 & Female & 28 & Teachers & Xiamen \\
P15 & Male & 21 & Students & Zhangzhou \\
P16 & Male & 20 & Students & Quanzhou \\
\hline
\end{tabular}

Source: Author's own compilation

\subsection{Interview Material}

Through Xiamen, Zhangzhou, Quanzhou city relative understanding and have living experience respondents' one-to-one depth interview, and interview content analysis, we concluded that consumers for the city perception of Xiamen word, and refining keywords, three-quarter or more respondents think Xiamen is a comfortable livable, inclusive open, beautiful environment, urban management is perfect, dynamic city. Two 
and two-thirds or more respondents believe that Zhangzhou is harmonious and friendly, honest, hospitable, and Quanzhou Xiamen and help each other. At the same time, two-thirds of the respondents believe that Quanzhou is a rich economic city of Fujian, is the starting point of the Silk Road always has the sense of responsibility of the times, give people the feeling of inclusive of everything, and is a city with strong historical heritage.

Table 4. Refining of Xiamen city brand interview materials.

\begin{tabular}{|c|c|c|c|c|}
\hline Dimensionality & Example List (16 Select 2) & Factor Extraction & \multicolumn{2}{|c|}{ Keyword } \\
\hline \multirow[b]{2}{*}{$\begin{array}{c}\text { Economic } \\
\text { Environment }\end{array}$} & \multirow[b]{2}{*}{$\begin{array}{l}\text { 1.Xiamen's special economic zone is the } \\
\text { "window", "experimental field" and } \\
\text { "vanguard" of modernization. They are } \\
\text { committed to exploring and open the way } \\
\text { and trying first. } \\
\text { 2.Xiamen has beautiful scenery, delicious } \\
\text { food, and comfortable environment, and } \\
\text { is a famous tourist city, known as } \\
\text { Oriental Hawaii. }\end{array}$} & \multirow[b]{2}{*}{$\begin{array}{l}\text { Good public security, } \\
\text { management, beautiful and } \\
\text { clean, open, and diversified, } \\
\text { comfortable, and livable, } \\
\text { perfect infrastructure } \\
\text { construction }\end{array}$} & Keyword & Frequency \\
\hline & & & $\begin{array}{l}\text { Comfort and } \\
\text { livable } \\
\text { Romantic } \\
\text { Environment } \\
\text { daintiness }\end{array}$ & $\begin{array}{l}10 \\
4 \\
3\end{array}$ \\
\hline Human History & $\begin{array}{l}\text { 1.Xiamen is a sea garden with excellent } \\
\text { charm. } \\
\text { 2.I think Xiamen coincides with the } \\
\text { leisurely world that I yearn for, and the } \\
\text { whole humanities is very inclusive and } \\
\text { open. }\end{array}$ & $\begin{array}{l}\text { Simple and honest, soft, and } \\
\text { rigid, has a long history, } \\
\text { inclusive, open, vitality, } \\
\text { literature, and art, fresh }\end{array}$ & $\begin{array}{l}\text { Literature } \\
\text { External soft } \\
\text { inside just } \\
\text { The style is } \\
\text { excellent } \\
\text { Full of vitality }\end{array}$ & $\begin{array}{l}3 \\
3\end{array}$ \\
\hline $\begin{array}{l}\text { Anthropo- } \\
\text { morphic } \\
\text { Features }\end{array}$ & $\begin{array}{l}\text { 1. Women, aged } 20-30 \text {, look clean, } \\
\text { enthusiastic, energetic, and creative, and } \\
\text { live a happy life. } \\
\text { 2.A32-year-old woman, soft and rigid, } \\
\text { generous, and reasonable, gentle, kind, } \\
\text { and healthy. }\end{array}$ & $\begin{array}{l}\text { Young and energetic, forge } \\
\text { ahead, indifferent to fame } \\
\text { and wealth, knowledgeable, } \\
\text { dignified, and elegant, } \\
\text { beautiful, healthy }\end{array}$ & $\begin{array}{l}\text { Young and } \\
\text { active } \\
\text { Tender and soft } \\
\text { as water } \\
\text { Bright } \\
\text { Pure and fresh }\end{array}$ & $\begin{array}{l}7 \\
3 \\
3\end{array}$ \\
\hline City Story & $\begin{array}{l}\text { 1.Xiamen is more energetic and beautiful, } \\
\text { just like the young youth of the new era. } \\
\text { 2.Xiamen contains everything without lack } \\
\text { of personality, with pleasant climate and } \\
\text { moderate pace of life, which makes } \\
\text { people feel full of enthusiasm and full of } \\
\text { emotional appeal. }\end{array}$ & $\begin{array}{l}\text { Clean and tidy, fighting } \\
\text { spirit, vitality, high quality, } \\
\text { pleasant climate, reasonable }\end{array}$ & $\begin{array}{l}\text { Modern feeling } \\
\qquad \text { Liven } \\
\text { Clean and tidy } \\
\text { High quality of } \\
\text { citizens }\end{array}$ & $\begin{array}{l}7 \\
6 \\
6 \\
3\end{array}$ \\
\hline
\end{tabular}

Source: Author's own compilation

Table 5. Refining of Zhangzhou city brand interview materials.

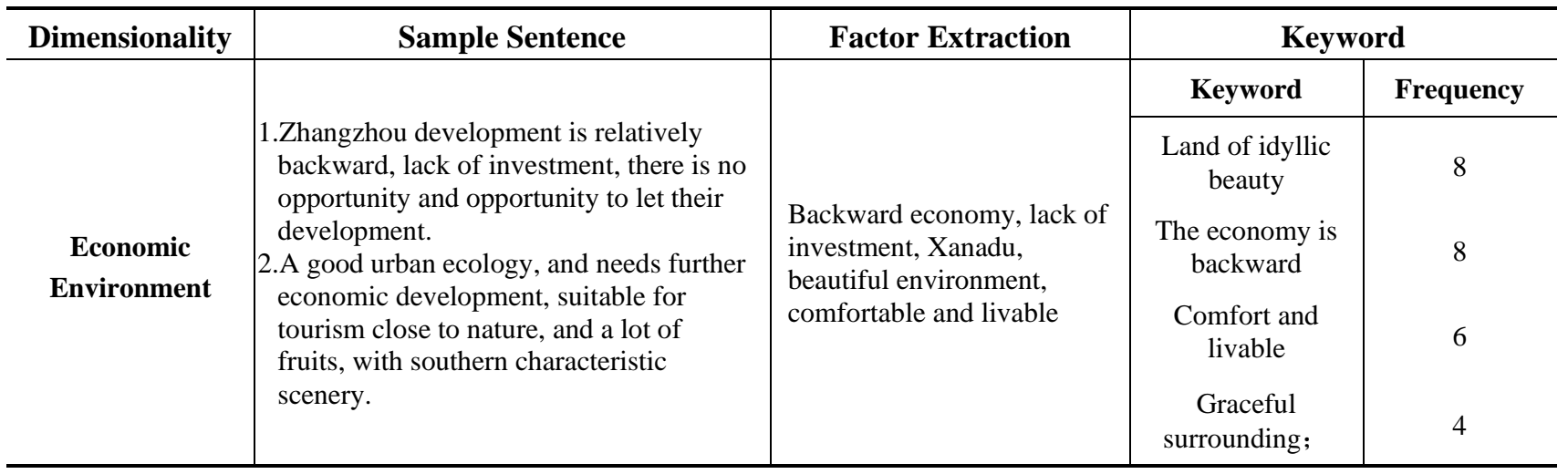


Table 5. Refining of Zhangzhou city brand interview materials (Cont.).

\begin{tabular}{|c|c|c|c|c|}
\hline \multirow{3}{*}{$\begin{array}{l}\text { Dimensionality } \\
\text { Human History }\end{array}$} & \multirow{3}{*}{$\begin{array}{l}\text { Sample Sentence } \\
\text { 1.Zhangzhou has a slow pace of life, low } \\
\text { people's living standard, more suitable } \\
\text { for enjoyment, hidden life. } \\
\text { 2. Full of primitive atmosphere, the city } \\
\text { has a long history will make people have } \\
\text { a unique rural feeling. }\end{array}$} & \multirow{3}{*}{$\begin{array}{l}\quad \text { Factor Extraction } \\
\begin{array}{l}\text { Simple atmosphere, a long } \\
\text { history, a slow pace of life, } \\
\text { comfortable }\end{array}\end{array}$} & \multicolumn{2}{|c|}{ Keyword } \\
\hline & & & Keyword & Frequency \\
\hline & & & $\begin{array}{l}\text { Have a long } \\
\text { historical } \\
\text { standing } \\
\text { Simple breath } \\
\text { The pace of life } \\
\text { is slow }\end{array}$ & $\begin{array}{l}9 \\
8 \\
6\end{array}$ \\
\hline $\begin{array}{l}\text { Anthropomorphi } \\
\text { c features }\end{array}$ & $\begin{array}{l}\text { 1.A } 65 \text {-year-old woman is relatively feudal } \\
\text { and backward, less tolerant and has her } \\
\text { own thoughts. } \\
2.50-60 \text { years old men, honest and honest, } \\
\text { honest, indifferent to fame and wealth, } \\
\text { carefree. }\end{array}$ & $\begin{array}{l}\text { Simple and kind, the image } \\
\text { of the elderly, considerate, } \\
\text { indifferent to fame and } \\
\text { wealth, hospitality }\end{array}$ & $\begin{array}{l}\text { Considerate } \\
\text { Friendly } \\
\text { Beautiful and } \\
\text { generous } \\
\text { Indifferent to } \\
\text { fame and wealth }\end{array}$ & $\begin{array}{l}4 \\
4\end{array}$ \\
\hline City Story & $\begin{array}{l}\text { 1.Zhangzhou is not developed, people's } \\
\text { living standards are relatively low, the } \\
\text { pace of life is relatively slow, giving a } \\
\text { person a feeling of carefree, just away } \\
\text { from the worldly noise like a paradise, } \\
\text { clean. } \\
\text { 2.Hospitable, simple, giving a sense of } \\
\text { intimacy, feeling like not having a good } \\
\text { opportunity and opportunities to develop. }\end{array}$ & $\begin{array}{l}\text { Slow development, slow } \\
\text { pace, living standards need } \\
\text { to be improved, poor, } \\
\text { simple, and kind, } \\
\text { hospitable, and historical } \\
\text { charm }\end{array}$ & $\begin{array}{l}\text { Simple and } \\
\text { honest } \\
\text { Slow rhythm } \\
\text { Low living } \\
\text { standards } \\
\text { Have historical } \\
\text { charm }\end{array}$ & $\begin{array}{l}8 \\
8 \\
7\end{array}$ \\
\hline
\end{tabular}

Source: Author's own compilation

Table 6. Refining of Quanzhou city brand interview materials.

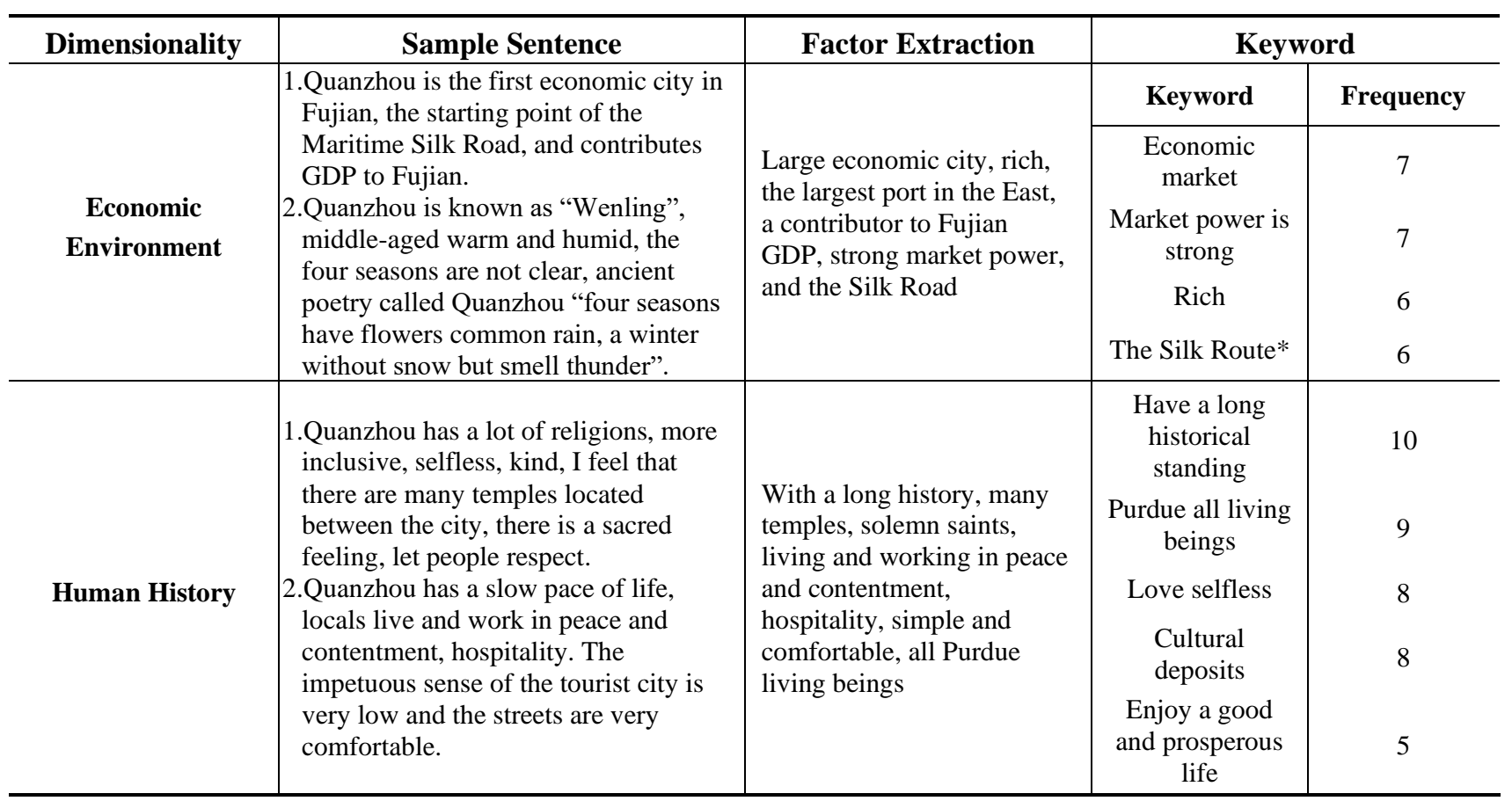

*A route over which Han silk fabrics and other products were transported to Southwest Asia and Europe 
Table 6. Refining of Quanzhou city brand interview materials (Cont.).

\begin{tabular}{|c|c|c|c|c|}
\hline Dimensionality & Sample Sentence & Factor Extraction & \multicolumn{2}{|c|}{ Keyword } \\
\hline & & & Keyword & Frequency \\
\hline $\begin{array}{l}\text { Anthropomorphic } \\
\text { features }\end{array}$ & $\begin{array}{l}\text { 1.Around } 60 \text { males, respected, } \\
\text { prestigious, religious, Purdue beings. } \\
\text { 2.A } 40 \text {-year-old male, a successful } \\
\text { person, is relatively open and } \\
\text { inclusive, very rich, colorful life, and } \\
\text { seriously lives in his own circle. }\end{array}$ & $\begin{array}{l}\text { Successful people, } \\
\text { respected, have a certain } \\
\text { prestige, believe in religion, } \\
\text { selfless love, mature and } \\
\text { stable }\end{array}$ & $\begin{array}{c}\text { Mature and } \\
\text { steady } \\
\text { Have prestige } \\
\text { Respected } \\
\text { Rich and } \\
\text { colorful } \\
\text { Have a } \\
\text { distinctive } \\
\text { flavor }\end{array}$ & $\begin{array}{l}10 \\
9 \\
7 \\
5 \\
3\end{array}$ \\
\hline City Story & $\begin{array}{l}\text { 1.Quanzhou feels that the city is very } \\
\text { urban, but the countryside is also very } \\
\text { rural, his pace is not slow and not fast, } \\
\text { I feel that living in Quanzhou is like } \\
\text { drinking a sip of lemon juice, began to } \\
\text { be a little sour, behind the aftertaste is } \\
\text { endless. } \\
\text { 2.The managers of the whole city are } \\
\text { very concerned about the lives of the } \\
\text { people, shoulder the mission of The } \\
\text { Times, and have a strong sense of } \\
\text { responsibility. }\end{array}$ & $\begin{array}{l}\text { Endless aftertaste, intimacy, } \\
\text { far-reaching, sense of } \\
\text { responsibility, sense of } \\
\text { mission, care for society, } \\
\text { rhythm is not happy }\end{array}$ & $\begin{array}{l}\text { Responsible } \\
\begin{array}{c}\text { Strong sense of } \\
\text { mission }\end{array} \\
\text { Care for society } \\
\text { Affect } \\
\text { profoundly } \\
\text { Pluralism }\end{array}$ & $\begin{array}{l}10 \\
7 \\
7\end{array}$ \\
\hline
\end{tabular}

Source: Author's own compilation

\section{Analysis Conclusion}

It can be seen from the content of the interviews that the public has different brand perceptions in the three cities of Xiamen, Zhangzhou, and Quanzhou. People's recognition, extraction and enhancement of city brands are all based on "emotional" linkage. The establishment of city brands strengthens people's sense of regional identity and cultural belonging. The use of 12 prototype characters can refine and upgrade the city symbols of Xiamen, Zhangzhou, and Quanzhou, highlighting the unique and differentiated urban connotation. Through matching analysis with 12 prototype characters in China, it is concluded that the brand image of Xiamen city is close to the prototype of "beautiful person", the brand image of Zhangzhou city conforms to the prototype of "neighborhood", and the brand image of Quanzhou city is close to the prototype of "benevolent". Exploring the brand image of the city is conducive to grasping the core value of the city brand and finding a more appropriate core positioning of the city. Leveraging on China's 12 cultural prototypes, we will build a personalized, vivid, and three-dimensional city brand with personality charm and emotional stories, strengthen the appeal and affinity of the city, and enhance the public's sense of identity with the city brand.

\section{Suggest}

\subsection{Position the City's Brand Image and Build the City's IP Image}

"Beautiful, comfortable, pleasant, modern" image of Xiamen has been deeply branded in the public heart, Xiamen should give play to its own urban advantage, using its unique urban charm, shaping elegant, delicate, fashionable "beauty" urban IP image, Xiamen as a "beautiful, free, dynamic, intellectual" urban modern woman, create close to "beauty" cultural atmosphere, artistic atmosphere, with more personality charm of city brand image.

When creating the IP image of the city, Zhangzhou can build a city brand close to the "neighborhood" spirit, give Zhangzhou a "simple, honest, harmonious and friendly, hospitable" city brand personality, arouse the emotional resonance of the public, and shorten the emotional distance with the public.

In the hearts of the public, Quanzhou is a city with strong historical and cultural heritage. As a large city of economic development in Fujian Province, it also retains rich historical heritage and religious culture. This is the important city personality of Quanzhou different from other cities, Quanzhou in building the city brand image, Quanzhou can make full use of the characteristics of the city, closer to the "benevolent" image, shaping Quanzhou into a "benevolent, tolerant, upright, strong sense of responsibility, sense of mission" "benevolent" image. 


\subsection{Build the City Brand Image with the Help of Short Video}

Mobile short video has the characteristics of low operation threshold, high utilization of fragmentation time, and easily cause "viral" transmission. Short video plays an important role in the road of city branding. Taking advantage of short video and taking advantage of Chinese 12 cultural prototypes, we will actively create a distinctive, key, and rich three-dimensional city brand image. In the short video, form the city unique label core brand concept, refined, sublimated, condensed, form a high repetition rate on the platform, concentrated play to the characteristics of concentrated traffic, the image of Xiamen, Zhangzhou, Quanzhou city brand deeply rooted in the hearts of the people.

\section{References}

1. Bao, S. L., \& Miao, L. (2021). The Application of Traditional Visual Symbols in City Brand Image Design. Art Research, 2: 152-153.

2. Li, J. K., \& Zhang, T. (2021). City Culture Branding and Communication. News Front, 9: 86-88.

3. Liu, Y. P., \& Wang, M. K. (2021). Research on High-quality Development of Chinese City Brand and Its Influencing Factors-Based on the Perspective of Coordinated Development Concept. China Soft Science, 3: 73-83.

4. Liu, Y. W., Wang, T., Zhou, L., \& Nie, C. Y. (2018) Research on Chinese Brand Culture Prototype: Theoretical Construction and Comparison Between China and the West. Journal of Marketing Science,14(1): 1-20.

5. Margaret, M., \& Carlo, S. P. (2003), Long, Long Ago: Building Deeply Rooted Brands with Mythic Archetypes. Translated by Xu Jinfu et al. Shantou: Shantou University Press.

6. Shao, J. F., Lu, M., \& Zhang, S. X. (2021). The Development of IP Image in City Brand Design: The Case of Xi'an "Tang Niu". Beauty and the Times (in Chinese), 7: 77-79.

(Editor: Yang Liu) 